\title{
Effect of Test Anxiety on the Music Performance of College Girl Students of Himachal Pradesh
}

\section{Dr. Mritunjay Sharma}

Anxiety

Anxiety is currently a central explanatory concept in most theories of personality and psychology, and is also widely regarded as a principle cause of such diverse behaviors as insomnia, and sinful acts and even instances of creative held- expression. For most persons, anxiety is distraction and discomforting. Anxiety may lower the self-esteem and limit the educational-vocational development. Anxiety can take a physical toll as well, and , may be involved in disease processes in several ways. Even the ingestion of drugs to relieve anxiety may lead to loss of self-control and decrease in held-efficacy along with the side affects of increased risk of serious accidents and drug abdication.

A growing number of researches in recent years have focused their attention on specific sources of anxiety, such as social anxiety, anxiety over public speaking and test anxiety, because those sources are of considerable intrinsic interest themselves also because of the nebulous character of the concept of general anxiety. Moreover, it is definable situational context. Anxiety is frequently observed in test situation by professionals in the fields of education and psychology. Now test anxiety has become the most widely studied of these specific, anxiety (See, Sarason, 1980). Test anxiety research is currently conducted by investigators working mostly within school settings and university laboratories allover the world. The last years have shown an increment in the frequency and quality of research on test anxiety. An increasing number of investigators from many countries have devoted more efforts in the investigation of test anxiety as a conspicuous emotional phenomenon in human experience. The research in characterized by a border heretical perspective integrating different advanced concepts from other fields in psychology, and by more international contributions including cross-cultural studied. In order ' to stimulate research on test anxiety, and to provide to a network for facilitating the communications of advances in theory and research, the society for Test Anxiety Research (STAR) started Advances in Test Anxiety Research series (Schwarzer \& Soilbertger, 1983, 1984), designs to document the most important advances in this field in the international scientific community (e.g Dutch, Van her Ploeg, 1982, Polish, Wrzesniwwake, 1984, Norwegian, Hagtvet, 1983, 1984, Sharma \& Sud, 1983, Sharma \& Rao, 1983, 1984 and Korean, Schwarzer \& Moonjoo Kim, 1984 ets.).

Research on test anxiety has witnessed substantial progress in recent years in concept differentiation, new theoretical approaches, empirical results and psychometric research methods. Topman \& Jansen (1984), nicely demonstrated how definitions of test anxiety have changed over time since 1920's. Also, the first three series advances in Test Anxiety Research, cover multiple approaches with respect to concept differentiation, methodology, psychometrics and applications to educational and clinical settings.

At various time, anxiety has been conceptualized as a response, a stimulus, a trait, a motive and a drive (Spielberger, 1972a, 1972b). One important source of ambiguity and confusion in the theory and research on anxiety stems from the fact that the terms stress and anxiety are used interchangeably. Another problem in anxiety research is the failure to distinguish between transitory anxiety states, anxiety as a complex psychobiological process, and individual differences in anxiety proneness as a personality trait (Spielberger, 1972a, 1972b, 1976). Consistent with theoretical developments and research findings, Spielberger (1972a) proposed that the terms stress and threat be used to denotes different aspects of a temporal of an anxiety reaction. while stress denotes the objective stimulus properties of a situation, threat refers to an individual's perception of a situation as more less dangerous or personally threatening to his. If a situation or though is perceived as threatening, irrespective of the presence of real or objective danger (Stress), the person who perceives the situation as threatening will experience an increase in state anxiety (A-State). A precise conceptual definition of the pattern of responses that characterizes anxiety as a transitory emotional state (AState) is necessary precondition for meaningful research on anxiety phenomenon. But the term to refer a relatively stable personality disposition to trait (i.e. relatively stable individual differences in anxiety proneness), and to a complex process that involves stress, threat and A-State. Anxiety as a process refers to a sequence of cognitive, affective, physiological and behavioral events. Therefore, a comprehensive theory of anxiety will require clarification of the concept of anxiety as a transitory emotional process (Spielberger 1975). It must be pointed out that most investigators have defined anxiety multiple components and each

1 Department of Performing Arts, Himachal Pradesh University, Shimla 
investigator has ended to include different aspects or components in his definition of the anxiety process. Even when investigators include the same components, they often use different descriptive terms in defining these variables. This means that standard terminological conventions are not yet established for describing critical variables involved in anxiety phenomenon.

On the basis of extensive research evidence, Sarason, 1972, 1978, 1984) concludes that high-test-anxiety individuals are more self centered and self critical than individuals who are low in test anxiety and more likely to emit personalized, derogatory response that interfere with task performance. This shift in emphasis seems particularly appropriate with regard to test anxiety. At least two projects have recently demonstrated that person low and high in test anxiety display equivalent degrees of physiological arousal while anticipating and taking test (Holland Sworth, Glazecki; Kirkland, Jonesa \& Van Norman, 1973 Holryd, Westbrook, Wolf \& Badhorn, 1978). In both of these projects, arousal was displayed both by person high in test anxiety and by persons low in test anxiety. The arousal was not greater among the test-anxious than among those who were not test-anxious (See, also Mahonbey, 1979, for conceptually similar findings from a different behavioral domain), carver \& Scheier, (1984) point out that different people are test anxious for different reasons. Hightest-anxious have chronic doubts about either producing adequate performance about examinations (Ellis, 1962) or being evaluated favorably by significant others (Wine, 1982). Persons low in test anxiety, on the other hand, are less doubtful and more condition. If the task is difficult, or situational anxiety is high, there by potentiating momentary interruptions, these classes of people should differ form each other in their responses. Further more, these differences should be exaggerated under conditions of high self focus. This self focussing aspect of test anxiety construct in a cognitive attentional approach to test anxiety (Sarason, 1972, 1978, 1984, Wine 1971, 1980, 1982).

Recently, Wine (1980) has proposed a bidirectional model of test anxiety and treated test anxiety as a multidimensional construct. This model throws light on the feelings and cognitions of low anxious individuals also. However, this model gone far beyond existing data and calls for detailed research examination. Like wine (1980), Meichenbaum (1980), Dusek (1980), Serber, (1980), in their thoughtful discussions have noted that test anxiety is a multidimensional construct and not a unitary construct. Further, Becker (1982), observed that test anxiety can also be conceptualized as a state, as a trait and as a process. He believed that a detailed analysis of test anxiety seen as process will be fruitful. From the forgoing discussion, test anxiety may be defined in terms of individual differences in anxiety proneness in examination situations. Post test anxiety theorists seem to agree that test-anxiety persons are more likely: (i) to perceive examination situation as more dangerous or threatening than do people who are low in test anxiety: and (ii) to experience worry cognitions and intense elevations in state anxiety in situations in which they are evaluated (see Spielberger, Gonzalez, Tayler, Algaze \& Anton, 1978).

\section{Statement of the Problem}

The problem is stated as under:

Effect of test anxiety on the music performance of college girl students of Himachal Pradesh.

\section{Objective}

The objective of the present investigation was to study the effect of test anxiety on the music performance of college girl students.

\section{Hypothesis}

Following hypothesis was formulated and tested:

There will be significant difference in the music performance of college girls having high, average and low level of test anxiety.

\section{Tools}

Test Anxiety Inventory by Spielberger was used for data collection. The scores obtained by the subjects in the practical examination were used for final analysis.

\section{Sample:}

A total sample of 400 girls studying Music in B.A. Part I, II and III was selected randomly from 20 colleges of Himachal Pradesh. Most of the subjects were of the age group 18 to 20 years. A few subjects were above 20 years in age. Table 1 . shows class-wise distribution of the sample. 
Table 1.1 Class-wise Distribution of the Sample

\begin{tabular}{|c|c|c|}
\hline S. No. & Class & N \\
\hline 1 & BA I & 90 \\
\hline 2 & BA II & 120 \\
\hline 3 & BA III & 90 \\
\hline Total & & 400 \\
\hline
\end{tabular}

In order to collect relevant data, the investigator approached authorities and teachers teaching music in the colleges to fix up the dates and time for the administration of tools. The Test Anxiety Scale was administered just before the practical examinations of the students studying music. This was necessary to determine the level of test anxiety among them. The scores obtained by them were also obtained for further analysis.

The students were assured that the purpose of the test was just academic and no information would be given to anyone else.

\section{Analysis of Data}

Data were analysed, employing 't-test'. The anxiety scores obtained by the subjects were put in ascending order. Three groups were formed namely High, Average and Low Anxiety Groups. Top 27\% of the students were placed in high anxiety group, bottom $27 \%$ students were placed in low anxiety group and middle $27 \%$ students were placed in average anxiety group. Thus there were 108 students in each comparison group. The achievement scores obtained by the students in three groups were taken for analysis. Table 1.2 shows the analysis of performance of music students in three anxiety groups.

Table 1.2 Comparison of Music Performance among High, Average and Low Anxiety groups of College Students.

\begin{tabular}{|c|c|c|c|c|c|}
\hline Comparison Groups & Mean 1 & Mean 2 & SD 1 & SD 2 & 't' \\
\hline G1 - G2 & 78.60 & 67.60 & 7.50 & 8.84 & $9.86^{* *}$ \\
\hline G1 - G3 & 78.60 & 60.00 & 7.50 & 8.36 & $16.41^{* *}$ \\
\hline G2 - G3 & 67.60 & 60.00 & 8.84 & 8.36 & $6.49^{* *}$ \\
\hline
\end{tabular}

$\mathrm{df}=214 ; \mathrm{t}=1.97$ at 0.05 level; $\mathrm{t}=2.59$ at 0.01 level

Table 1.2 reveals the means, standard deviations and ' $t$ ' -values for various comparison groups formed on the basis of their levels of test anxiety. It is clear that the value of 't' for comparison groups G1 and G2 (Students having low level of anxiety and students having average level of anxiety) is 9.86 which is significant at 0.01 level of confidence. The value of 't' for comparison groups G1 and G3 (Students having low level of anxiety and students having high level of anxiety) is 16.41 which is significant at 0.01 level of confidence. Also the value of 't' for comparison groups G2 and G3 (Students having average level of anxiety and students having high level of anxiety) is 6.49 which is also significant of 0.01 level of confidence.

Thus, it is evident that these comparison groups differ significantly in their music performance. On the inspection of the means form Table 1.2 it is clear that mean for students having low level of anxiety (78.60) if greater than the mean for students having average level of test anxiety (67.60). Similarly the mean for students having high level of test anxiety (60.00) is far less than the means for the low and average groups (78.60; $67.60)$.

Thus it may be concluded that as the level of test anxiety goes on decreasing, the music performance of students goes on becoming better. This is in conformity with the researches conducted on test anxiety and achievement. Hence the hypothesis that "There will be significant difference in the music performance of college girls having high, average and low level of test anxiety,' is confirmed.

\section{Discussion}

Music is a subject where practical performance is give top priority. Music requires talent as well as regular practice along with a calm state of mind. Students who become anxious have, even otherwise, been found to perform poorly. Anxiety cripples their muscular coordination and also diverts their attention from the performance. Examinations are notorious in increasing the level of anxiety among the students of the subjects where practicals are quite demanding. Thus students offering music are no exception. Studies have shown time and again that there is a negative and significant relationship between anxiety and the academic performance. 
Sarason (1978, 1980, 1981); Sarason and Stoops (1978); Sud (1983), Covington (1983); Wine (1971) and Sharma and Dasgupta (1993) found that anxiety and academic performance were negatively correlated. Results obtained by Sharma (1978) and Grewal and Sud (1981) also confirmed the findings of the present investigation.

Rao (1974); Osterhouse (1975) Gaudry (1978) and Deffenbacher (1978) have also found negative relationship between test anxiety and academic achievement in both college and school students. In case of other anxiety and academic achievement studies, majority of studies reported low negative but significant correlation (Sinha, 1961, 1966; Singh, 1966; Hundal et a1., 1972; Sinha, 1972; Rao, 1974 and Vishnoi, 1975).

The results of the present investigation are also supported by the studies conducted by Nazma and Satyanarayana (1978) in which they found out that the relationship of test anxiety with scholastic achievement is negative i.e. as anxiety increases, the achievement decreases.

\section{Bibliography}

Abramowitz, S.1. Internal-external control and social political activism: A test of the dimensionality or Rotter's I-E Scale. J. of Cons. \& Clinical Psy., 1973, 40 (2), 196-200.

Abrams-Goidel, M. The relationship between the ability to perceive nonverbal communication cues, field dependence-independence and intelligence. Unpublished Ph.D. Thesis. City Univ. of New York, 1982.

Agathan, M. and Salehi, Role of family and social factors in the antecedents of locus of control: Interest in the concept for the psychotherapies. Revue de Psychologic Appliquee, 1982,32, (3), 63-79.

Aggarwal, Y.P. and Kumari, Manju. A study of locus of control as a determinant of academic achievement. Kurukshetra University Research Journal (Arts and Humanities), 1974, VII, 1-2.

Ahuja, T. A study of field dependence - independence and locus of control as function of sex and academic achievement in urban rural high school students. Unpublished M.Phil. Dissertation, Himachal Pradesh University, 1981.

Allen, GJ. The behavioral treatment of test anxiety: Recent research and future trend: Behavior Therapy. 1973, 3. 253- 262.

AI-Khafaji, T.S. The relationship between I-E LOC, educational level, age and gender. Unpublished Ed. D. Thesis Univ. Northern Colorado, 1981.

Amir, Y. Inter and intra ethnic comparisons of intellectual functions in Israeli and Middle Eastern Population. Abstract Guide of the Twentieth International Congress of Psychology, Toyko, 1972, $175-176$.

Amster, lB. and Lazarus, P.J. Locus of control of disadvantage high school dropouts preliminary data. Perceptual and Motor Skills, 1982, 55, 13332-1334.

Arbuthnot, J. Cautionary note on measurement of field independence. Perceptual and Motor Skills, $1972,35,479-488$.

Arbuthnot, 1 Sex, sex-role identity and congnitive stuyle. Perceputal and Motor Skills, 1975, 41 (2), 435-440.

Barclay, A. and Cusumomo, D.R. Father absence, Cross-sex indentity and field dependent behaviour in adolescents. Child Development, 1967, 38, 243-252.

Barks and Sinha. Cited in J.e. Raven, J.H. Progressive Matrices and Vocabulary Scales Section 3, Standrad Progressive Matrices. 1.e. Raven Ltd. London: H.K. Lewis and Ltd., 1977.

Barking, J. and Bolon, K. Multidimensional locus of control: The case of white south African students. Jr. of Social Psychology, 1980, [II, 295-296.

Barling, 1. and Fincham, F. Locus of control beliefs in Indian and White school children in South Africa. Jr. of Cross-Cultural Psychology, 1978,9,2.

Barling, 1. Meternal antecedents of children's multidimensional locus of control beliefs. Jr. of Genetic Psy., 1982, 140(1), 155-156.

Baron, R.M. Social reinforcement as a function of social reinforcement history. Psychological Review, 1966, 73, 527.,.537.

Barry, H., Child; Kifr, F; Barzohar, Y and Chen, M. The relationship between locus of control and academic achievement, anxiety and level of aspiration. British J. of Edu. Psy. Feb. 1980,50 (1) 53-60.

Battle, E.S. and Rotter, J.B. Children's feelings of personal control as related to social class and ethnic group. Jr. of Personality, 1963, 31, 482-490.

Carment, D.W. Internal versus external control in India and Canada. International Jr. of Psychology. 1974.9.45-50. 
Carrier, N.L. and Jowell, D.O. Efficiency in measuring the effect of anxiety upon academic performance. Jr. of Edu. Psy, 1966,57,23-28.

Cattell, RB. and Scheir. I.H. (1963) Handbook for the IPAT anxiety scale. (Second edition), Chanpagne, Illinois: Institute for Personality and Ability Testing.

Christensen, Heidi (1979) Test anxiety and academic achievement in high school students. Pereptual and Motor skills, (Oct.)Vol. 49 (2). 468.

Daviels. B. \&. Hewitt, J. Anxiety and classroom examination performance. Journal of Clinical Psychology, 1987, Apr. 3492) 340-345.

Decker, T.W. Two approaches in the treatment of lest anxiety college under-achievers. Dissertation Abstracts International. 1 '978, No. 8- A (Vol-38).

Deffenbacher, J.L. \& Dietz, S.R Effects of test anxiety on performance worry and emotionally in naturally occuring exams. Psychology in the schools, 1978,5,446-450.

Deffenbacher, J.L. \& Hanlosar, R.M. A comparison of congnitive restructuring and progresive relaxation in test anxiety reduction. Unpublished manuscript, Colorado State University, 1978.

Deffenbahcer. J.L.Worry and emotionality in test anxiety In I.G. Sarson (Ed.). Test Anxiety: Theory, Research and Application. Hillsdale. N.J.Ear1baum, 1980.

Deffenbacher.J.J. Relationship of worry and emotionality to performance on Miller Analogies Test. Jr. of Ed. Psy. 1977 April 69 (2) 191-195.

Endler, N.S. Anxiety, aptitude and academic achievement; Ontario. J. of Edu. Research. 1964. 81 85-91.

Fabick, S.D. The relative effectiveness of systematic desensitization, congnitive modification and mantra mediation in the reduction of test anxiety. Dissertation Abstracts International. 1977,4862 (A-6).

Finger, RV. Galassi, J.P. Effects of modifying congnitive verus emotionality responses in the treatment of test anxiety. J. of Consulting and Clinical Psychology. 1977,45. 280-287.

Fleschers, I. Anxiety and achievement of intellectually gifted and creatively gifted children, J. of Psy. 1963, 56, 251-268.

Frierson, H.T. Jr. The association of test performance intervention, with test performance on a standardization professional entrance examination for minority students Health Pathways, 1979,4 (2), $1-2$.

Gakhar, S \& Luthrs, S. Effects of Anxiety and test administration on creative performance. Creativity News Letter. 1974, 3. 9-17

Galassi, J.P.; Frierson, H.T. Jr. \& Sharer, R Behaviour of high, moderate and low test anxious students during the actual test situation. Journal of Consulting and Clinical Psychology. I 98 I, 49 (I), 51-62.

Gunguli, P. Anxiety and academic achievement. Asian Journal of Psychology and Education. 1981,7.39-43.

Garza, RT. and Ames. RE. A comparsion of Angloand Mexican Amercian college students on locus of control. Jr. of consulting and Clinical Psychology. 1974,42, 919.

Gaudry, E and Spielberger, D. Test anxiety, intelligence and academic achievements. Quoted in Gaudry and Spielbcrger (Eds.) Anxiety and Educational Achievements. N. York. John Wiley \& Sons. 1971, 155152.

Hogan, H.- W Academic performance as a function of self estimates, intelligence and Anxiety. Indian Journal of Psy. March, 1978, 53(1), 15-19.

Holroyd, K.A.; \& Appel. M.A. Test anxiety and physiological responding. In I.G. Sarason (Ed.) Test Anxiety: Theory, Research and Application. Hillsdale. N.J. Lawrence Erlbaum Associates. 1980, 129-151.

Hundal, P.S. \& Kaur S. Study of Cattel's anxiety scale questionnaire in India. Journal of Psychological Researches, 1978, I K. 41-45.

Hundal et al. Factor analysis study of measures of anxiety, intelligence and academic achievement. Jr. of Psy. Research, 1972, 16,28-34.

Hwang, C.L. A study of the I-E Control of Chinese school pupils, Bulletin of Educational Psy. 1979, 12, 114.

Jorgensen, C.C. Expectancies about achievement and the sense of internal-external locus of control and academic performance among Black High Schools students. Jr. of Black Psychology. 1976, 2 (2) 5263.

Jutshi, C. (1983) Factor analysis of the Hindi version of the TAL Unpublished, Master of Philosophy Dissertation, H.P. University. Shirnla.

Kanckar, S. Academic performance in relation to anxiety and intelligence, Jr. of Soci. Psy. 1947. Feb. 10 I (I) 153-154. 
Kalur, D. The effects of test of anxiety, locus of control and intelligence of academic achievement in school children Unpublished, 1982. Master of Philosophy Dissertation, Punjab Univ. Chandigarh.

Keller, E.D. and Rowley, V.N. Relation Among Anxiety intelligence and Scholastic achievement in Jr. of Edu. Research 1964, 58, 169-170.

Kestendaum, J.M. and Meiner, B. Achievement performance related to achievement motivation and test anxiety. Jr. of Consulting \& Clinical Psy. 1970.34.343-344.

Lefcouret, H.M. Locus of control: Current trends in theory and research. Hillsdale, N.J. erlbaum 1976.

Lefcourt, H.M. Recent developments in the study of Locus of Control. In B.A. Mayer (Ed.) Progress in Experimental Personality Research in Experimental Personality Research. Vol. 6. Academic Press. N.Y. and London. 1972.

Lent, RW. \& Morris, L.W. Cognitive and emotional components of test anxiety: A distinction and some initial data. Psychological Reports. 1967,20.975-978.

Lewis, J. and Adank R. Inter correlation among measures of intelligence, achievement, self-esteem and anxiety in the groups of elementary school pupils exposed to two different model's of instructions. Edu. \& Psy Measurement, 1975,35 (2) 499-501.

Little, S; Jackson B. The treatment of test anxiety through attention and relaxation training. Psychotherphy: Theory and Practice. 1974, 11, 175-178.

Mac. Donald, Jr. A.P. Internal-external locus of control: Parental antecedents. Jr. of Clinical and Consulting Psychology. 1971,37 (I), 141-147.

Mandler, G. and Sarason, S.B- The effect of prior experiment and subjective failure on the evaluation of test anxiety. Jr. of Personality, 1953. 21 338-341.

Mandler, \& Sarson, S.B. A study of anxiety and learning. Journal of Abnormal and Social Psychology, 1952,47. 166-173.

Marchetti, A., Mcglynn, P.D. \& Patterson, A.S. Effects of cue controlled relaxation a placebo treatment and no treatment on changes in self report and psychological indices of test anxiety among college students. Behavior Modification, 1977,1.47-72.

Merriman, E.,P. Effects of manifest anxiety of the riding achievement of 5th grade students. Jr. of Experimental Edu. 1974,42 (3), 36-41.

Osterhouse, RA. Classroom anxiety and the examination performance of test anxious students. Jr. of Edu. Research 1975 (Mar), 68 (7) 247-250.

Parsons, O.A., Schneider, 1.M. Locus of control in university students from eastern and western societies. Jr. of Consulting and Clinical Psy. 1974, 42, 456-461.

Pleg, H.M. Van der; Schwarzer, R \& Spielberger, C.N. (Eds.) 1983. Advances in test anxiety research Vol (2). Lisse: Swets and zeitlinger.

Promad Bala. A study of test anxiety scale and general anxiety scale for children as applied to a sample of secondary school children. Unpublished M.A. thesis. P.U. 1966.

Prell, S. The infulence of examination anxiety on different achievement measures. Psy in Rrziehing and Unlerricht 1973.20 (I) 14-30.

Rao, S.N. Academic achievement and anxiety. Psychological Studies. 1974. 19 (I) 38-42.

Rayamohan, G.A. Study of locus of control and academic motivation among college students. Asian Jr. of Psy and Edu. 1978,3 (2) 52-55.

Reed, R \& Meyer, RG. Reducation of test anxiety via antogenic therapy. Psychological Reports. 1974, 35, 649-650.

Rosenthal, T.L. Modeling approaches to test anxiety and related performance problems. In I.G. Sarason (Ed) Test Anxiety: Theory, Research and Application. Hillsdale, N.J: Lawrence Erlbum Associated. 1980.

Russell. RK; sipich, J.P. Treatment of test anxiety by sub-controlled relaxation. Behavior Therapy. 1974, 5. 673-676.

Salame, R.F. Test Anxiety: Its determinants, manifestation and consequences. In H.M. Van del' ploeg. R. Schwarxer and CD. Spileberger (Eds.) Advances in Test Anxiety Research (Yol.3.) Lisse: Swets and Zeitlinger, Hilbsdale N.J. Lawrence Erlbllm Associates. 1984, pp.83-119.

Sarason, I.G. Empirical findings and theoretical problems in the use of anxiety scales. Psychological Bulletin. 1960, 57, 403-415.

Sarason, I.G. Test anxiety and intellectual performance. Journal of Abnormal and Social Psychology. 1963, 66. 73-75. 
Sarason, I.G. Experimental approaches to test anxiety attention and the uses of information. In C.D. Spielberger (Ed.) Anxiety: Current Trends in Theory and Research (Vol. 2) N.York. Academic Press. (a), 1972.

Sarason, I.G. Test anxiety and cognitive modeling. Journal of Personality and Social Philosophy, 1973 28, 5861.

Sarason, I.G. Test anxiety, attention and general problem of anxiety. In C.D. Spileberger \& I.G. Sarason (EDs). Stess and Anxiety. Vol. 1. Washington. D.C. Hemisphere, 1975.

Sarason, I.G. The Test Anxiety Scale: Concept and research In C.D. Spielberger \& I.G (Eds.) Stress and Anxiety Vol. 5. Washington D.C. Hemispher, 1978.

Sarason, I.G. Test anxiety: theory, researched applications. Hillsdale N.J. Lawrence Erlbaum Unde, 1981.

Schwarzer, R. Test anxiety, SES, and scholastic achievements. Psychology in Erziehung unde un terrified 1975,22 (I) 16-22.

Sharma, S. Research on anxiety in India: A review. Indian Journal of Psychology. 1978, 53. 29-43.

Sharma, S.; Sud, A. \& Spileberger, C.D. Development of the Hindi form of the test anxiety inventory. In H.M. Van del' ploeg, R. Schwarzer \& C.D. Spileberger, (Eds.) Advances in Test Anxiety Research Vol-2. Lisse Swets \& Zeithlinger. Hillsdale N.J. Lawrence Frlnbaum, 1983, 183-190.

Sieber, J.E. Defining test anxiety. Problems and approaches. In I.G. Sarason. (Ed) Test Anxiety Theory, Research and Application. Hills data N.J. Erlbay, 1980.

Singh, B. \& Kumar P. Anxiety and educational achievements. Journal of Psychological Research, 1977, 21, 56-62.

Spileberger, C.D. Theory and research and anxiety In C.D. Spielberger (Ed) Anxiety and Behavior N.Y. Academic Press, 1966.

Spileberger, C.D. (1975) Anxiety state trait process. in C.D. Spileberger \& I.G. Sarason (Eds.) Stress and Anxiety. Vol-I. Washington C.D. Hemisphere, 1975.

Spileberger, C.D. Test Anxiety Inventory, Preliminary professional manual for the test anxiety inventory. (Test Attitude Inventory) TAL Palo Alto. Cal. Consulting Psychologists Press, 1980.

Wine. J. Cognitive attention theory of test anxiety. In I.G. Sarason (Ed) Test Anxiety: Theory, Research and Application. Hills dale N.J. Erlballm. 1980. 